\title{
Behavioural Economics Contribution to the Entrepreneurship Theory and its Application in Entrepreneurship Policies
}

\author{
Natalia P. Dobryagina
}

Russian Presidential Academy of National Economy and Public Administration (North-West Institute of Management, Branch of RANEPA), Saint-Petersburg, Russian Federation; dobryagina-np@ranepa.ru

\begin{abstract}
Based on interdisciplinary research the paper proves that behavioural economics provides a significant contribution to the entrepreneurship theory and can increase the effect of policies focused on entrepreneurship motivation. The paper demonstrates that entrepreneurship is a phenomenon, which contradicts a number of neoclassical assumptions, while behavioural economics provides explanations of these deviations and embeds entrepreneurship into modified models. These new models take into account behavioural aspects of entrepreneur's decision. The paper determines three main reasons of restrained effect of entrepreneurship policies, which are limited knowledge about existing entrepreneurship policies, underestimation of entrepreneurial sphere opportunities and importance of non-pecuniary factors in entrepreneurial decision, which are not taken into account in existing entrepreneurship determinants, used by policy makers. The paper suggests that behavioural economics approaches should be used in entrepreneurship policies as they help to deal with similar issues in other spheres.
\end{abstract}

Keywords: behavioural economics, entrepreneurship, theory of entrepreneurship

For citing: Dobryagina N.P. Behavioural Economics Contribution to the Entrepreneurship Theory and its Application in Entrepreneurship Policies // Administrative consulting. 2021. N 1. P. 50-60.

\section{Вклад поведенческой экономики в теорию предпринимательства и ее использование в государственной политике в сфере предпринимательства}

\section{Добрягина Н.П.}

Российская академия народного хозяйства и государственной службы при Президенте Российской Федерации (Северо-Западный институт управления РАНХиГС), Санкт-Петербург, Российская Федерация; dobryagina-np@ranepa.ru

\begin{abstract}
PЕФЕРАТ
Основываясь на междисциплинарном исследовании, статья доказывает, что поведенческая экономика вносит значительный вклад в теорию предпринимательства и может усилить эффект государственной политики, ориентированной на мотивацию предпринимательства. Статья демонстрирует, что предпринимательство - это явление, которое противоречит ряду неоклассических предположений, в то время как поведенческая экономика дает объяснения этим отклонениям и включает предпринимательство в модифицированные модели. Данные модели учитывают поведенческие аспекты предпринимательских решений. В статье определены три основные причины, из-за которых государственная политика в сфере предпринимательства имеет ограниченное воздействие: недостаточные знания о существующей политике, недооценка возможностей и перспектив предпринимательской сферы и важность нематериальных факторов в предпринимательском решении, которые не учитываются в существующих детерминантах предпринимательства, применяемых в государственной политике поддержки предпринимательства. В статье рассматривается возможность использования инструментов поведенческой экономики в государственной политике поддержки предпринимательства, основываясь на успешном опыте применения данных подходов в других сферах.
\end{abstract}

Ключевые слова: поведенческая экономика, предпринимательство, теория предпринимательства 
Для цитирования: Добрягина Н. П. Behavioural Economics Contribution to the Entrepreneurship Theory and its Application in Entrepreneurship Policies // Управленческое консультирование. 2021. № 1. С. 50-60.

\section{Introduction}

Entrepreneurship provides significant contribution to the economic development of any country [50], and though entrepreneurship is a quickly developing research field [46] and it received sufficient attention recently [48; 49], existing theory only partly explains the phenomenon due to the absence of a clear border between entrepreneurs and other economic agents [54] and also due to behavioral biases, which influence entrepreneurial behavior [4], but contradict neoclassical economic models [34].

The lack of attention to behavioral insights also leads to a decreased efficiency of entrepreneurship policies due to the fact that potential entrepreneurs have a biased perception of both external and internal factors, influencing entrepreneurial decision. The biases in entrepreneurial decision making process are common [61] and appear due to limited access to information, biased estimates [56], overoptimism [4], framing effect [63; 65], overconfidence [11,37] entrepreneurial persistence [1], entrepreneurship passion [43] and other psychological factors [30; 4; 10; 53].

The paper will consider the theoretical foundation of entrepreneurship and contribution of behavioral economics to the existing theory. The paper will also identify the key factors, which decrease the effect of existing entrepreneurship policies and will demonstrate how behavioral economics can help in dealing with these issues.

\section{Entrepreneurship and economic theories}

\section{Static models of entrepreneurship}

Economics of entrepreneurship is one of the quickly developing research fields, which demands new economic models and assumptions [46]. In the neoclassical growth theory, the contribution of entrepreneurship to the economic growth was not taken into account. The classical approaches in economics include the equilibrium model with a perfect competition and zero profits, while appearance of entrepreneurship assumes opportunities for non-zero profits and absence of equilibrium on the market. Due to this reason, entrepreneurship as an economic phenomenon was not considered in neoclassical growth models; however, the obvious contribution of entrepreneurship to the economy demanded a closer consideration of the phenomenon and inclusion of entrepreneurship into growth models.

The early theories of entrepreneurship include works by Knight [35], who stressed the importance of risk and uncertainty in entrepreneurship. Knight used the term "risk" for the so-called measurable uncertainty, in case of which the possible outcomes and their probabilities are known; "uncertainty" in this case implies that probabilities can't be calculated. Uncertainty is considered as the key factor of entrepreneurial activity. Knight emphasises the difference between the worker's and entrepreneur's attitude to risk, he argues that uncertainty is the reason of profits existence (the idea that is considered as an alternative to the perfect competition model, which assumes zero profits). Uncertainty, according to Knight, appears due to individual's partial knowledge. Knight mentions earlier works by Mithoff, according to which the entrepreneur's income consists of rents, wages, and a "profit", which might be considered as a remuneration for taking the risk of failure. Despite the fact that uncertainty, according to Knight, explains profit and loss, profit, when it occurs, is not precisely a "reward for risk-taking," however the income expectation is the incentive to consider the entrepreneurial career. 
Another important contribution to the theory of entrepreneurship was made by Schumpeter (1934) who emphasised the importance of entrepreneurs as a power that brings innovation to the economy (the event that is followed by imitation process). The Schumpeter's long-cycles hypothesis determines innovation as a process, which has an initiating role. He argues that entrepreneurs initiate economic change and influence consumers' behaviour. Schumpeter also introduces a concept of a "new combination", which includes five possible cases: the introduction of a new good or a new quality of a good, introduction of a new method of production, discovering of a new market, new source of supply and a new organization of an industry. The new combination appears due to the entrepreneur's innovative activity, which demands sufficient credit. Entrepreneurs might receive the necessary credit from banks and capitalists, due to what innovation and credit are strongly linked in the process of economic change.

Another contribution of Schumpeter includes the psychological explanation of the entrepreneur's behaviour, such as the will to found a private kingdom, to conquer and the joy of creation. Through the psychological peculiarities of entrepreneurs, Schumpeter points our attention to the non-financial motivating factors.

Knight and Schumpeter emphasise not only the relevance and importance of entrepreneurship consideration in economic theories, but also the importance of behavioural characteristics of entrepreneurs.

A significant contribution to the theory of entrepreneurship was made by Israel Kirzner. He mentioned the fact that neoclassical economic models have unrealistic assumptions, such as perfect knowledge. The reality though is a proof of existence of a number of undiscovered opportunities. According to Kirzner, people don't perceive all possible opportunities of mutually beneficial exchange [34]. Kirzner introduces the concept of "entrepreneurial alertness", which implies the ability to realize the opportunities on the market, and search for the ways of implementing them in order to receive profits. The concept of alertness assumes that there are individuals who have this ability, while the other individuals don't.

Other theories of entrepreneurship consider entrepreneurship as an alternative to work in an organisation. One of such models is the Occupational Choice model. This model considers all agents as homogeneous and according to a static model if pi > $w$ (where pi is a profit from entrepreneurship and $w$ is a wage) an individual chooses to become an entrepreneur [67]. More complex models include risk factor, difference in attitude to risk [33] and idea of heterogeneous entrepreneurial ability [42]. While the difference in attitude to risk was mentioned in much earlier works by Knight, the heterogeneity of abilities adds a new perspective. The model assumes that heterogeneous abilities create heterogeneous income for entrepreneurs, while salaries of workers are assumed equal. This assumption emphasises the higher level of complexity in models, which take into account entrepreneurship.

In macroeconomic theories, entrepreneurship is considered from other perspectives. In Banerjee and Newman model [6], the primary goal of entrepreneurship is to create wealth. The authors direct attention to the economic development of a country and the role of "evolution of occupational patterns". They build a model, which is focused on the interconnection between the process of development and the pattern of occupational choice. They strongly emphasise the importance of entrepreneurship in economic development of a state.

Another model proposed by Calvo and Wellisz [12] considers technology and technological progress as factors, which determine the occupational choice of entrepreneurs. They attract attention to the role of external factors, which form entrepreneurship.

According to Shane and Venkataraman [54], the entrepreneurial function assumes identification, analysis and utilization of opportunities, creation of new products, services or processes; application of new strategies and search for new markets. 
Research in the sphere of business capabilities demands differentiation between entrepreneurs, managers and capitalists; however, in some cases one individual might perform the functions of all three agents [17]. The problem of agent's differentiation represents a significant difficulty in entrepreneurship research.

According to the Cuervo and Ribeiro [17] classification, entrepreneurs, capitalists and managers are diversified according to their different characteristics and behaviours (as can be seen in Table 1).

From the Table 1, one can assume that during the period of the firm's growth an entrepreneur might become a capitalist or a manager, acquiring such characteristics as risk aversion and rational decision making. That directs us to the idea that entrepreneurship can be considered from a dynamic perspective.

If we'll think about entrepreneurship as a possible stage, then application of a dynamic model might be a useful instrument in the phenomenon study. Dynamic model includes time in its structure. If we consider two time periods $t=0$ and $t=1$ and two possible states: Entrepreneur - E and Capitalist - C, we can say that an individual, being entrepreneur in time period 0 might become a capitalist in time period 1 , depending on the amount of capital accumulated in period 1 and other factors, which include behavioral characteristics of an individual.

Another dynamic perspective on entrepreneurship is presented in the Global Entrepreneurship Monitor (GEM) study, one of the world's leading research on entrepreneurship, according to which entrepreneurship can be considered as a process which starts from opportunities and skills identification and leads entrepreneur to the stage of ownermanager of an established business. The GEM identifies the so-called Early-Stage Entrepreneurial Activity (TEA), which represents the period between Potential Entrepreneur and Owner-Manager of established business (Fig. 1).

Despite the fact that all the phases are determined as parts of the entrepreneurship process, this research points readers' attention to the fact that entrepreneurship might be a stage in one's career, which leads to the non-entrepreneurial activities of an individual. In case of entrepreneurs, the transition to other forms of economic activities might be relatively fast and not easy to trace. The "owner-manager of established business" phase in the GEM report might lead to the loose of such entrepreneurial characteristics as innovation, application of new strategies and creation of new products [54]. The absence of a clear border between entrepreneurs and other economic agents creates additional complications in entrepreneurship research and analysis.

\section{Behavioural Theory Applicability in Economic Models}

While entrepreneurship is a challenging direction of research, application of Behavioural Economics turns out to be a logical and necessary perspective to be taken into account while considering entrepreneurship as an economic process. In the previous paragraph, the Cuervo classification of entrepreneurs, capitalists and managers presented behavior as one of the key differences between agents. The basic idea of Behavioural Economics is to understand the economic behaviour and its consequences [14]. Dating back to 1960s Behavioural Economics "increases the explanatory power of economics through more realistic psychological foundations" [13]. While standard economic models are based on a strong assumption of human's rationality, Behavioural Economics points researchers' attention to psychological, emotional and social factors which influence individual's decisions. Daniel Kahneman and Amos Tversky [31] developed the so-called Prospect Theory, which explains the role of cognitive psychology in individual's decisionmaking process that often demonstrates deviations from the neo-classical theory 
Entrepreneurs, Managers and Capitalists (Cuervo and Ribeiro, 2007)

\begin{tabular}{|l|l|l|l|}
\hline \multicolumn{1}{|c|}{ Entrepreneur } & \multicolumn{1}{c|}{ Capitalist } & \multicolumn{1}{c|}{ Manager } \\
\hline Characteristics & $\begin{array}{l}\text { Discovers and } \\
\text { exploits } \\
\text { Opportunities } \\
\text { Initiator and } \\
\text { motivator of change }\end{array}$ & $\begin{array}{l}\text { Capital owner: } \\
\text { shareholders } \\
\text { Controlling } \\
\text { shareholder } \\
\text { Passive shareholder }\end{array}$ & $\begin{array}{l}\text { Administrates and } \\
\text { manages resources } \\
\text { An administrator }\end{array}$ \\
\hline Behaviour & $\begin{array}{l}\text { Accepts risks } \\
\text { Uses intuition, } \\
\text { explores new business } \\
\text { Leadership, initiates } \\
\text { new ways of acting } \\
\text { Identifies business } \\
\text { Opportunities } \\
\text { Creation of new firms }\end{array}$ & $\begin{array}{l}\text { Rissesses } \\
\text { alternatives }\end{array}$ & $\begin{array}{l}\text { Risk averse } \\
\text { "Rational” decision- } \\
\text { maker } \\
\text { Exploits business } \\
\text { Creates and } \\
\text { maintains } \\
\text { competitive } \\
\text { advantage } \\
\text { Creates trust to } \\
\text { enhance cooperation }\end{array}$ \\
& \multicolumn{2}{|l}{} \\
\hline
\end{tabular}

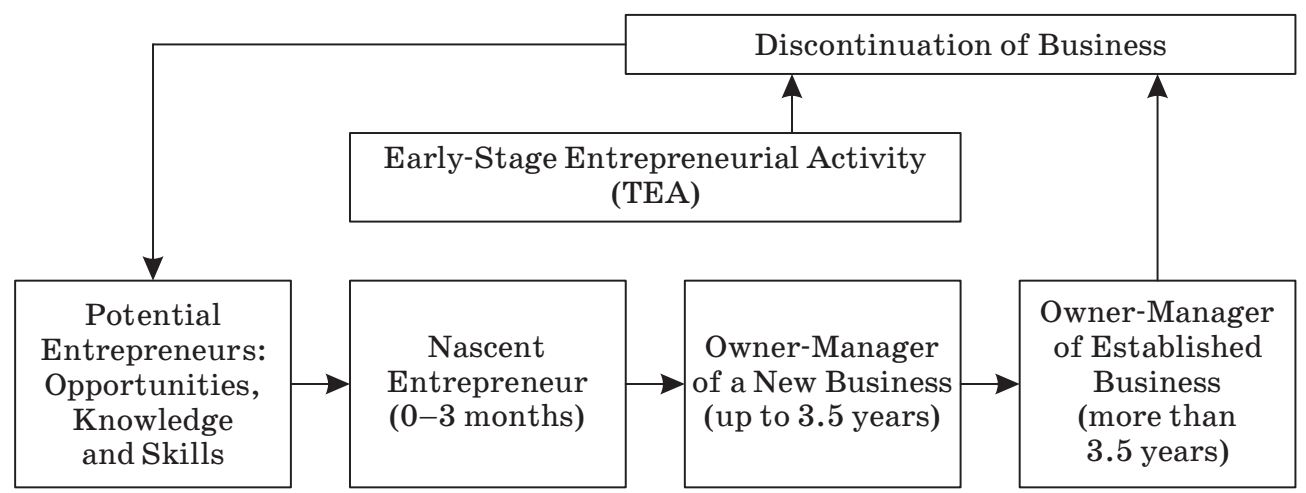

Figure. The Entrepreneurship Process (GEM, 2014)

assumptions. Kahneman and Tversky described the risk averse and risk seeking behaviour of individuals when the decision context includes full information about alternatives and their probabilities.

Behavioural Economics led to the appearance of the term "bounded rationality". Herbert Simon in 1978 won a Nobel Prize for his pioneering research of the decision making process within economic organisations, in which he led the reader to the idea that homo economicus is not a good approximation of real behaviour. Simon proved that the concept of economic man should be replaced by "a kind of rational behaviour", which takes into account limited access to information, limited computational capacities of an individual and the influence of the decision making context. In his later works Simon also mentions the influence of emotions and feelings on individual's decision.

Despite the fact that BE introduces a number of ideas, which contradict neoclassical model assumptions, it doesn't reject the neoclassical approaches which use utility theory and maximization. Behavioural Economics enriches the theory by adding greater predictability to the models and by helping to identify better policies. Behavioural approaches are successfully applied in classical models and represent improved versions 
of Marshallian and Hicksian demand [21], reference dependent utility [14], the utility of sequences [41] and other models.

BE adds a number of concepts, which focus the researchers' attention on the reasons of limited rationality. These concepts include the cognitive biases, which represent propensity to think in a certain way what leads people to a systematic deviation from rational behaviour. Another important concept, introduced by BE is heuristics, which are simplified approaches to problem solving, which minimize the time, spent on decision making, but doesn't guarantee the optimal choice. Heuristics include intuitive guess, stereotypes, rules of thumb, which are the simplifying rules helping individuals to make decisions faster with smaller time costs, what can lead to decision biases.

Cognitive biases include reference dependent utility when people evaluate their satisfaction or happiness through comparison with other people. The so-called framing effect which assumes that choice of an individual or his answer to a certain question depends on the way the question was asked. The endowment effect, which can be explained through reference dependence and loss aversion [40]. Bounded awareness described by Bazerman and Moore [8], which represents a process when people "routinely overlook important information during the decision-making process." One of the types of biases, which represent a separate group, is the emotional bias. The effect of emotional biases as well as cognitive biases is similar; they decrease the rationality in individual's decision making process. Despite the fact that emotions, beliefs and subjective opinions often become a reason of a decision bias, they might also represent decision criteria and important influencing factors in decision making process. Paying greater attention to the non-pecuniary factors and decision criteria, Behavioral Economics improves predictability of new economic models.

\section{Behavioural Economics Contribution to the Theory of Entrepreneurship}

Behavioural Economics can provide a strong contribution to the theory of entrepreneurship through explaining the deviations from the neoclassical assumptions about individual's decision making process. One of the examples of such deviations is the fact that people become entrepreneurs in spite of low risk-adjusted returns [24], in other words, in spite of the fact that the earnings from entrepreneurship where proven empirically to have low medium value with very high variance [53]. This observation can't be explained by a standard utility function, and it contradicts the fact that most people "have utility function that implies risk aversion" and have preference to less-variable pay [4]. One of the explanations, which was widely considered in earlier theories, was the idea that an entrepreneur is a more risk-seeking person; however, as it was clearly shown in the review of studies by Parker [46], there is no statistically significant difference between entrepreneurs and control group individuals in terms of risk attitude. Another research by Holm, Opper and Nee [27] also doesn't identify any significant difference in attitude to risk between entrepreneurs and employees. Thomas Asterbo [4] mentions this fact as one of the reasons why BE should be taken into account in entrepreneurship analysis. One of the inputs of Behavioural Economics to the entrepreneurs' behaviour explanation is the identification of the overconfidence as one of the explaining factors of entrepreneurs' decision making process. It was proven empirically that entrepreneurs "subjectively perceive the return distribution too favourably when evaluating their own entrepreneurial project." [15]. A more detailed analysis was presented in a book by S. Parker [46], which mentions two distinct characteristics of entrepreneurial decision makers, which are overoptimism, meaning the overestimation of probability of success, and overconfidence, which is the underestimation of variation of the outcomes. The overoptimism according to Moore et al. [46] appears because of 
cognitive bias, due to which a person overestimates his abilities and underestimates competition.

In the book by Cuervo et al. [17], Behavioral Economics contribution to the entrepreneurship theory is presented as a thorough investigation of entrepreneurial abilities, such as ability to search and gather information, to identify opportunities, to deal with risk, to establish relationships and networks, etc. Behavioral approach is contrasted to the psychological as psychological, according to the authors, considers the unchangeable personality of an individual, while behavioral approach considers skills and abilities, which can be gained.

Krueger [38] proposed an intentions-based model, which explains the entrepreneurial behavior, pointing attention to the cognitive peculiarities of an entrepreneur as a decision maker. He argues that on the base of robust empirical research the intentions-based model assists in identifying cognitive infrastructures that influence the way individual perceives opportunities. Shane, S. A. and Venkataraman, S. [54] consider cognitive properties of different individuals which influence their ability to discover the entrepreneurial opportunities. From the authors' perspective, decision consists of weighing the value of an opportunity and comparing it to the costs of generating that value. Entrepreneurial persistence is another reason, which determines the quality and quantity of entrepreneurship in a region [44].

Another important aspect of entrepreneurs' decision making is the non-pecuniary benefits of being entrepreneur. The fact that policy makers underestimate the importance of non-financial factors in entrepreneurial decision, received attention recently [18; 19]. For example, in the sphere of agriculture importance of non-financial motivation of potential entrepreneurs is discussed by a number of authors [32; 26]. The research on behavioural aspects of entrepreneurship represents a promising field of study, which might find a significant practical use in entrepreneurship policies.

\section{Behavioural Economics and Entrepreneurship Policies}

Application of behavioural insights in public policies design received significant attention in a number of countries $[9 ; 57]$. According to Troussard and van Bavel recent paper behavioral insights can be used on each stage of the EU policy cycle [64]. On the stage of policy preparation, behavioral insights assist in problem identification. On the next stage, it can be introduced into the EU policy instruments. Behavioral economics can be also used on the policy preparation stage as an instrument to model policies, which are more focused on behavioral change. At the stage of policy application behavioral insights help in cooperation with authorities.

A number of policies were developed on the base of behavioral economics. These policies include "traffic lights" system for healthy, neutral and unhealthy food, green energy supplier as a default option, public educational campaigns in the sphere of safety on roads, programs against obesity and smoking and many others [60]. Another cluster of research suggests application of behavioral economics on the stage of policy impact assessment [22] in order to improve the effectiveness of a policy and increase the level of policy acceptance by society.

However, application of behavioral economics in the sphere of entrepreneurship policies demonstrates a different situation. The field of entrepreneurship policies research is nascent [29]. The role of public policy on entrepreneurship is not always clear for the policy makers [66]. Reasons of a limited application of behavioral economics might lie in narrow research on entrepreneurship, as discussed in the previous sections.

The effect of existing entrepreneurship policies is often limited [51]. Applying behavioral economics perspective, this paper identifies three issues, which are responsible for it. The first issue is connected with a limited knowledge about current entrepreneurship 
policies among potential entrepreneurs [3]. A recent case of Behavioral Insights Team (BIT) project in Turkey (2017) demonstrates a clear example of this. Turkey's Ministry of Trade offered assistance to businesses in order to motivate them to start exporting. However, part of the annual budget on the program was not spent. BIT discovered that it was connected with the fact that entrepreneurs simply didn't know about this opportunity.

The second issue is the biased perception of entrepreneurial career opportunities. The bounded awareness bias, considered earlier in this paper, assumes that an individual always have limited knowledge about business opportunities, which he/she considers. In other words, decision makers have subjective perception of entrepreneurial sphere and might significantly underestimate it by one or several criteria, such as innovativeness, profitability and others. Agricultural sphere of entrepreneurship represents one of the examples, when not objective perception of the sphere's opportunities decreases the entrepreneurship motivation policies efficiency. It was proven that agricultural business is falsely considered as not prestigious [36; 39; 47], not innovative [20] and not profitable [58; 23].

The third issue is the fact that non-pecuniary determinants of entrepreneurial choice are not taken into account in existing entrepreneurship determinants, considered by policy makers, although their importance was demonstrated in existing literature on entrepreneurship. A career choice with entrepreneurship as a career option was modeled by different researchers [16]. Recent papers take into account not only financial, but also non-financial determinants of entrepreneurial career [59; 46] and non-financial benefits are often called by entrepreneurs as key determinants of entrepreneurial career choice [28]. Despite this, entrepreneurship determinants, considered by policy makers, don't take into account non-financial benefits of entrepreneurial career [2]. OECD classification of entrepreneurship determinants, demonstrated in "Entrepreneurship at a Glance" includes regulatory framework, market conditions, access to finance, knowledge creation and diffusion, entrepreneurial capabilities and culture. Behavioral aspects of entrepreneurial decision making drop out of policy makers perspective. Behavioral Economics, in contrasts, gives great significance to non-pecuniary group of benefits in entrepreneurial decision making process [4], due to what policies, which apply behavioral insights, might increase the number of entrepreneurs in a sphere due to the effect of non-financial expected benefits.

Behavioural economics provides a number of instruments, devoted to dealing with the presented issues. One of these instruments is choice architecture [25], which allows to investigate the individual's decision making process in order to identify the behavioural reasons of not starting a business in a certain sphere. Choice architecture is an instrument in a bigger group of behavioural insights tools called NUDGES, which is "any aspect of the choice architecture that alters people's behaviour in a predictable way without forbidding any options or significantly changing their economic incentives" [62]. Behavioural insights tools of creating clear and understandable messages to citizens are already used by policy makers in a number of spheres. For example, in the sphere of food and nutrition in order to help people make healthier choices colour-coded labelling is used [22]. Behavioural economics application, which assumes a deep analysis of individual's decision making process [7] will unavoidably identify and solve the issues, faced by entrepreneurship policies such as problems of the lack of knowledge, biased perception and non-financial factors, influencing behaviour as these issues are already successfully solved in other spheres, where public policies are implemented with the help of behavioural insights [25; 22].

\section{Conclusion}

The paper has demonstrated that application of Behavioral Economics in entrepreneurship policies can increase the effect of these policies due to a number of reasons. Firstly, 
because entrepreneurial behavior is better explained by behavioral economics in contrast to neoclassical models, which provide contradictory explanations of entrepreneurial choice, attitude to risk and gives limited attention to non-financial motivating factors. Behavioral economics explains the key deviations of entrepreneurship phenomenon from neoclassical models. It considers factors, which influence entrepreneurial behavior, such as overoptimism, overconfidence, entrepreneurial persistence and impact of non-pecuniary decision criteria. The paper determines three issues of limited effect of entrepreneurship policies, connected with behavioral factors. The first issue is a lack of knowledge about existing entrepreneurship policies among potential entrepreneurs. The second issue is unobjective perception of entrepreneurship opportunities and underestimation of the sphere. The third issue is importance of non-financial criteria in entrepreneurial decision making process, which are not taken into account in entrepreneurship determinants, used by policy makers. Behavioral economics application in other spheres of public policies demonstrate successful elimination of these issues.

\section{References/Литература}

1. Adomaco S., Danso A., Uddin M. and Damoah J. O. Entrepreneurs' optimism, cognitive style and persistence //International Journal of Entrepreneurial Behavior \& Research. 2016. N 22 (1). P. 84-108.

2. Ahmad N. and Hoffman A. A Framework for Addressing and Measuring Entrepreneurship // OECD Statistics Working Paper N 2. 2008.

3. Algate F. 'You have been selected': Driving uptake of government schemes. [An electronic resource] // Behavioural Insights Team Blog. 2015. URL: http://www. behaviouralinsights.co.uk/ trial-results/you-have-been-selected-driving-uptake-of-government-schemes (date of the address: 05/08/2019).

4. Asterbo T., Herz H., Nanda R., Weber A. Seeking the roots of entrepreneurship: Insights from Behavioural Economics // Journal of Economic Perspectives, 2014. N 28 (3). P. 49-70.

5. Audretsch D., Grilo I., Thurik R. Handbook of research on entrepreneurship Policy. London: Edward Elgar Publishing, 2007.

6. Banerjee A. V., Newman A. F. Occupational choice and the process of development // Journal of Political Economy. 1993. N 101. P. 274-298.

7. Barr M.S., Mullainathan S., Shafir E. Behaviorally informed regulation. In behavioral foundations of public policy. Princeton, NJ: Princeton University Press, 2013.

8. Bazerman M., Moore A. Judgment in managerial decision making. New York: Wiley, 2012.

9. Bell C. Inside the coalition's controversial 'Nudge Unit' [An electronic resource] // The Telegraph. 2013. URL: https://www.telegraph.co.uk/news/politics/9853384/Inside-the-Coalitions-controversial-Nudge-Unit.html (date of the address: 23.06.2018).

10. Benartzi S., Thaler R. Heuristics and biases in retirement savings behavior // Journal of Economic Perspectives. 2007. N 21 (3). P. 81-104.

11. Brundin E., Gustafsson V. Entrepreneurs' decision making under different levels of uncertainty: the role of emotions // International Journal of Entrepreneurial Behavior \& Research. 2013. N 19 (6). P. 568-591.

12. Calvo G., Wellisz S. Technology, entrepreneurship and firm size // Quarterly Journal of Economics. 1980. N 95. P. 663-677.

13. Camerer C. Behavioural Economics: past, present and future // Advances in Behavioural Economics. Princeton: Princeton University Press, 2004.

14. Cartwright E. Behavioural Economics. New York: Routledge Taylor \& Francis Group, 2011.

15. Cooper A., Woo C., Dunkelberg W. Entrepreneurs perceived chances for success // Journal of Business Venturing. 1998. N 3 (2). P. 97-108.

16. Costa S. F., Caetano A., Santos S. C. Entrepreneurship as a career option: do temporary workers have the competencies, intention and willingness to become entrepreneurs? // The Journal of Entrepreneurship. 2016. N 25 (2). P. 129-154.

17. Cuervo A., Ribeiro D., Roig S. Entrepreneurship. Concepts, theory and perspective. New York: Springer Berlin Heidelberg, 2007.

18. Dobryagina N. Decision theory application in agricultural entrepreneurship promotion. Working Paper. Sapienza Universita di Roma, 2017. 
19. Dobryagina N. Agricultural entrepreneurship motivation policies: European Union experience and decision theory application // International Journal of Rural Management. 2019. N 15 (1). P. $97-115$.

20. Fursdon D. We need to get young people excited about farming [An electronic resource] // The Guardian. 2013. URL: https://www.theguardian.com/commentisfree/2013/aug/16/youngpeople-farming-future-agriculture (date of the address: 20.06.2019).

21. Gabaiz X. A Sparsity-based model of bounded rationality // The Quarterly Journal of Economics. 2014. P. $1661-1710$.

22. Goyens M. Using behavioural economics for rather than against consumers - a practitioner's perspective // Intereconomics. 2018. N 53 (1). P. 12-17.

23. Green D. Who wants to farm? Hardly any young people, it seems. Should/Could that change? [An electronic resource] // From Poverty to Power. Oxfam. 2014. URL: https://oxfamblogs.org/ $\mathrm{fp} 2 \mathrm{p} /$ who-wants-to-farm-hardly-any-young-people-it-seems-shouldcould-that-change/ (date of the address: 17.07.2019)

24. Hamilton B. H. Does entrepreneurship pay? An empirical analysis of the returns to self-employment // Journal of Political Economy. 2000. N 108 (2). P. 604-631.

25. Hausman D. Nudging and other ways of steering choices // Intereconomics. 2018. N 53 (1). P. $17-20$

26. Herath G., Prato T. Using multi-criteria decision analysis in natural resource management. New York: Routledge, 2016.

27. Holm H.J., Opper S., Nee V. Entrepreneurs under uncertainty: an economics experiment in China // Management Science. 2013. No 59 (7). P. 1671-1687.

28. Hurst E., Pugsley B. What do small businesses do? // Brookings Papers on Economic Activity. 2011. N 43(2). P. 73-142.

29. Irawati D. Handbook of research on entrepreneurship policy // International Journal of Entrepreneurial Behavior \& Research. 2008. N 14 (4). P. 263-266.

30. Isiwu P.I., Onwuka I. Psychological factors that influences entrepreneurial intention among women in Nigeria: a study based in south east Nigeria // The Journal of Entrepreneurship. 2017. N 26 (2). P. 176-195.

31. Kahneman D., Tversky A. Prospect Theory: an analysis of decision under risk // Econometrica. 1979. N 47 (2). P. 263-291.

32. Keeney R., Raiffa H. Decisions with Multiple Objectives. New York: Wiley, 1976.

33. Kihlstrom R.E., Laffont J.J. A general equilibrium Entrepreneurial Theory of firm formation based on risk aversion // Journal of Political Economy. 1979. N 87. P. 719-749.

34. Kirzner I. Perception, opportunity and profit. Chicago: University of Chicago Press, 1979.

35. Knight F. M. Risk, Uncertainty and profit. New York: Houghton-Mifflin, 1921.

36. Kotler N. Sharing innovation. Global perspective on food, agriculture and rural development". New York: Smithsonian Institutions Press, 1990.

37. Krawczyk M. Are we all overconfident in the long run? Evidence from one million marathon participants // Journal of Behavioral Decision Making. 2017. N 30(3). P. 719-730.

38. Krueger N. F. The cognitive infrastructure of opportunity emergence // Entrepreneurship Theory and Practice. 2000. N 24 (3). P. 5-23.

39. Leavy J., Hossain N. Who wants to farm? Youth aspirations, opportunities and rising food prices // Institute of Development Studies. 2014. N 439. P. 1-44.

40. List J. Neoclassical theory versus prospect theory: evidence from the marketplace // Econometrica. 2004. N 72. P. 615-625.

41. Loewenstein G., Prelec D. Preferences over sequences of outcomes // Psychological Review. 1993. N 100. P. 91-108.

42. Lucas R. On the Size Distribution of Business Firms // The Bell Journal of Economics. 1978. N 9 (2). P. 508-523.

43. Ma C., Gu J., Liu H. Entrepreneurial passion and organizational innovation: the moderating role of the regulatory focus of entrepreneurs // Journal of Developmental Entrepreneurship. 2017. N 22 (3). P. 1-19.

44. Millan J. M., Congregado E., Concepción R. Persistence in entrepreneurship and its implications for the European entrepreneurial promotion policy// Journal of Policy Modeling. 2014. N 36 (1). P. 83-106.

45. Moore D., Healy P. J. The trouble with overconfidence // Psychological Review. 2008. N 115 (2). P. 502-517.

46. Parker S. C. The Economics of entrepreneurship. Cambridge: Cambridge University Press, 2009. 
47. Peters R. Rural Entrepreneurship // EU Rural Review. The Magazine from the European Network for Rural Development. 2012. N 10.

48. Salisu I., Hashim N., Galadanchi A.H. Entrepreneurial career resilience and entrepreneurial career success: Does entrepreneurial career commitment matter? // Management Science Letters. 2019a. N 9 (1). P. 73-90.

49. Salisu I., Hashim N., Galadanchi A. H. Social capital and entrepreneurial career resilience: The role of entrepreneurial career commitment // Management Science Letters. 2019b. N 9 (1). P. $139-154$.

50. Sapinn E. (2016) 7 ways entrepreneurs Drive Economic Development" [An electronic resource] // Entrepreneur. URL: https://www.entrepreneur.com/article/283616 (date of the address: 07/08/2019).

51. Sarfati G. Do public policies for entrepreneurship make a difference? Prospective scenarios for Canada, Ireland and Italy // Future Studies Research Journal. 2012. N 4 (1). P. 114-139.

52. Schumpeter J.A. The theory of economic development. Cambridge MA: Harvard University Press, 1934.

53. Shane S. A. Fool's gold? The truth behind angel investing in America. Oxford: Oxford University Press, 2009.

54. Shane S., Venkataraman S. The promise of entrepreneurship as a field of research // The Academy of Management Review. 2000. N 25 (1). P. 217-226.

55. Simon H. A behavioural model of rational choice // Quarterly Journal of Economics. 1955. N 69. P. 99-118.

56. Smith A., Marshall L. Confidently biased: comparisons with anchors bias estimates and increase confidence // Journal of Behavioral Decision Making. 2017. N 30 (3). P. 731-743.

57. Subramanian C. R. 'Nudge' back in fashion at White House . [An electronic resource] // Time Swampland Blog, 2013. URL: http://swampland.time.com/2013/08/09/nudge-back-in-fashionat-white-house/ (date of the address: 03/08/2019).

58. Sulaiman N., Abdullah A. Factors that influence the interest of youths in Agricultural Entrepreneurship // International Journal of Business and Social Science. 2013. N 4 (3). P. 288-302.

59. Sullivan P. Estimation of an occupational choice model when occupations are misclassified// The Journal of Human Resources. 2009. N 44 (2). P. 495-535.

60. Sunstein C. R., Reisch L. A. Behavioral economics and public opinion // Intereconomics. 2018. N 53 (1). P. 5-7.

61. Swartz E., Amatucci F. Framing second generation gender bias: implications for women's entrepreneurship // Journal of Developmental Entrepreneurship. 2018. N 23 (2). P. 1-17.

62. Thaler R., Sunstein C. Nudge: improving decisions about health, wealth and happiness. New Have: Yale University Press, 2008.

63. Tombu M., Mandel D. When does framing influence preferences, risk perceptions, and risk attitudes? The explicated valence account // Journal of Behavioral Decision Making. 2015. N 28 (5). P. 464-476.

64. Troussard X., Bavel R. How can behavioral insights be used to improve EU policy? // Intereconomics. 2018. N 53 (1). P. 8-12.

65. Tykocinski O., Amir I., Ayal S. Embracing chance tactically: a different perspective on risk taking // Journal of Behavioral Decision Making. 2017. N 30 (3). P. 683-692.

66. Wiklund J., Davidsson P., Audretsch D., Karlsson C. The future of entrepreneurship research // Entrepreneurship Theory and Practice. 2011. N 35(1). P. 1-9.

67. Wit G. Models of self-employment in a competitive in a competitive market // Journal of Economic Surveys. 1993. N 7. P. 367-397.

\section{About the author:}

Natalia P. Dobryagina, Associate Professor of the Chair of State and Municipal Administration of North-West Institute of Management, Branch of RANEPA (St. Petersburg, Russian Federation), PhD; dobryagina-np@ranepa.ru

\section{Об авторе:}

Добрягина Наталья Павловна, доцент кафедры государственного и муниципального управления Северо-Западного института управления РАНХиГС (Санкт-Петербург, Российская Федерация), PhD; dobryagina-np@ranepa.ru 